\title{
FATTENING AND SOME CARCASS CHARACTERIRICS OF MERIZ AND NATIVE GOAT MALE KIDS RAISED IN EITHER CONCENTRATE OR PASTURE CONDITIONS
}

Kamal N. S. Dosky

Dept. of Animal Production, College of Agriculture, University of Duhok. Duhok, Iraq kamalnoman@yahoo.com

\begin{abstract}
The aim of this study was to determine the fattening and carcass characteristics of Meriz and goat kids raised in either intensive or pasture conditions. Twelve intact weaned male kids from each of Meriz and goat were weighed and blocked into three groups according to different feeding systems for 90 days. The $1^{\text {st }}$ group was given ad libitum concentrate mixture (intensive), the $2^{\text {nd }}$ was freely grazed on pasture for 45 days and then transferred to having ad libitum concentrate for 45 days (Semi-intensive), the $3^{\text {rd }}$ one was freely grazed on pasture (extensive). At the end of the experiment, all kids were weighed, slaughtered and the weight of their carcass was recorded. Daily gain in weight averaged $0.06 \pm 0.008$ $\mathrm{kg}$, the difference between breeds was not significant. Kids raised intensively surpassed significantly $(\mathrm{p}<0.05)$ kids on semi-intensive and on pasture $(0.10,0.06$ and $0.02 \mathrm{~kg} /$ day) respectively. Also breed has no significant effect on carcass and edible and non-edible organs weight or percentages (except the weight of pelt and the percentage of pelt and feet). Intensively and semi-intensively raised kids had significantly $(p<0.01)$ higher carcasses, dressing percentages, larger eye muscle area and thicker of fat thickness than those raised on pasture.
\end{abstract}

\section{INTRODUCTION}

Small ruminant animal husbandry is the most important living source for people inhabiting in regions not suitable for crop cultivation and cattle production. In addition, goat are well adapted to the environmental and limited feed and utilized marginal land to produce high protein product (Kadim et al., 2003). The native goat with a population of 1.6 million head (FAO, 2000) is an important livestock species in Iraq and raised primarily for milk and meat which are consumed in most regions of Iraq particularly in Kurdistan. Also there is a world wide tendency for rapid increase in demand for goat meat (Stankov et al., 2002) due to several reasons including the desire for leaner meat by consumer (Potchoiba et al., 1990), a good source of desirable fatty acids (Banskalieva et al., 2000) and reducing the risk of cardiovascular disease (Stankov et al., 2002).

It is well known that the most significant variable cost in any livestock operation is the feed cost. However, Daskiran et al.,(2006) concluded that pasture group kids had similar slaughter and carcass characteristics values as intensively ones. Meriz goat is found in Iraqi Kurdistan region and raised primarily for its fine hair (Alkass and Juma, 2005).However, information related to the potential of this breed as well as native goat for meat production is scare, therefore the aim of the present study is to establishment of their yield capacity and for the evaluation as a genetic resource, together with the effect of feeding system on fattening and carcass traits. 


\section{MATERIALS AND METHODS}

This experiment was conducted in the animal farm, College of Agriculture, University of Duhok when a total of 12 weaned male kids (3 months old) from each of native goat and Meriz obtained from commercial flock were used.

After an adaptation period for 7 days, the kids from both breeds were weighed and assigned to 3 groups according to different feeding systems for a period of 90 days. The first group (intensive) was given ad libitum concentrate mixture (Table 1). The second group of kids was freely grazed at commercial flock by the shepherd for 45 days and then transferred to have ad libitum concentrate mixture for 45 days. The third group of kids was freely grazed on pasture (Little cherry, Oriental Hawthern, Valonia Oak, Kochi Thyme, Mediterrance Stinkbush and Meikle Shifshen) by the shepherd for all experimental duration. Drinking water was supplied ad libitum during the experimental period. All kids were weighed biweekly. Group one and two from each of goat and Meriz were kept in separate pens and fed on group basis. Concentrate was offered daily at 9.00 a.m after quantitifying the refusal of the previous day.

Table (1): Ingredient and chemical composition of diet.

\begin{tabular}{|l|c|l|c|}
\hline Items & \% of diet & \multicolumn{3}{|l|}{ Chemical analysis \% * } \\
\hline Barley & 53 & Dry matter & 93.89 \\
\hline Wheat bran & 25 & Crude protein & 16.6 \\
\hline Soybean meal & 15 & Ether extract & 3.68 \\
\hline Wheat straw & 6 & Organic matter & 94.37 \\
\hline Salts & 0.5 & Ash & 5.63 \\
\hline Limestone & 0.5 & Crude fiber & $28.45^{* *}$ \\
\hline Vitamins $* * *$ & 0.5 & NFE & 65.44 \\
\hline
\end{tabular}

* Determined at nutrition lab., Animal Production Dept.

** Calculated according to AlKhawaje et al., (1978).

*** The vitamins were mixed with concentrate as an additive.

At the end of experiment, kids were weighed after fasting for $12 \mathrm{hrs}$ with the free access to water, and slaughtered and dressed according to commercial practices followed in Iraq at the College of Agriculture abattoir. The dressed carcass comprised the body after removal of the head, skin, fore and hind feet, kidney, kidney fat, and viscera. The weights of head, skin, feet, testes, some visceral organs (lungs, liver, heart, spleen and kidneys) were recorded. The gastro-intestinal tract was weighed, emptied, washed and weighed to facilitate calculation of empty body weight.

Carcasses were weighed before chilling and hot dressing percentage was calculated from the ratio of hot carcass weight to slaughter weight or empty body weight. After $24 \mathrm{hrs}$ of chilling $\left(4^{\circ} \mathrm{C}\right)$, all carcasses were weighed and joined into whole sale cuts. The Longissimus dorsi muscle area (Rib eye area) at the $11^{\text {th }}$ and $12^{\text {th }}$ ribs was determined by tracing the muscle on semi-transparent waxed paper, and the area was measured using the compensating planometer. Fat thickness over the Longissimus dorsi muscle was measured by verernia.

The data obtained was analyzed by using the GLM (General Linear Model) within SAS (2001) program as in the following model: 
Where:

$$
Y i j k=\mu+B i+F j+B F(i j)+e i j k
$$

Yijk = Observational value of $\mathrm{k}^{\text {th }}$ animal.

$\mu=$ Overall mean

$\mathrm{Bi}=$ Effect of $\mathrm{i}^{\text {th }}$ breed $(\mathrm{i}=$ Meriz, goat $)$.

$\mathrm{Fj}=$ Effect of $\mathrm{j}^{\text {th }}$ feeding system $(\mathrm{j}=$ intensive, semi-intensive, extensive $)$.

$\mathrm{BF}(\mathrm{ij})=$ Effect of interaction between $\mathrm{i}^{\text {th }}$ breed and $\mathrm{j}^{\text {th }}$ feeding system.

Eijk = Experimental error assumed to be NID with $\left(0, \sigma^{2} \mathrm{e}\right)$.

Since the results reveal no significant effect of interaction on all studied traits, therefore the data was re-analyzed without interaction.

Duncan multiple range test (1955) also used to test the difference between the subclasses of each factor.

\section{RESULTS AND DISCUSSION}

Growth performance: The findings related to fattening performance (initial and final weight, empty body weight and average daily weight gain ) are presented in Table 2- The overall mean of daily gain in weight was $0.060 \pm 0.008 \mathrm{Kg}$ (Table 2). This value is within the range (49.0-110g/day) reported earlier for Iraqi native goat (Ayied, 1996 and Mayi ,2009 ). Moreover, as MC Gregor (1985) had stated that growth rate of goat can vary from $30 \mathrm{~g} /$ day for the small tropical breeds to over $200 \mathrm{~g} /$ day for large European breeds and South African Boer breed.

The growth rate of both Meriz and goats was almost the same $(0.06 \mathrm{Kg} / \mathrm{day})$. However, Mayi (2009) found that the growth rate of Meriz was insignificantly higher than that of goat (98.73 vs. 75.98 g/day). Similarly, Kanaujia et al. (1985), Lu and Potchoiba (1990) Anous et al., (1993) and Kadim et al. (2003) noticed that the effect of breed on growth rate was not significant.

In the present study, significant differences $(p<0.05)$ was found among kids raised on different feeding regime on growth rate and consequently on final and empty body weights. The highest gain in weight was attained by kids raised intensively on concentrate $(0.100 \pm 0.01 \mathrm{Kg}$ /day $)$ followed by semi-intensive kids $(0.060 \pm 0.008 \mathrm{~kg} /$ day $)$ and finally kids raised on pasture $(0.02 \pm 0.005 \mathrm{Kg} /$ day $)$. Similarly, Oman et al. (1999) found that feedlot goats had heavier $(\mathrm{P}<0.05)$ live weights $(38.17 \mathrm{~kg})$ than did range goats $(20.51 \mathrm{~kg})$.

Table (2): Means and S.E. for fattening performance of Meriz and native goat raised in different feeding regimen.

\begin{tabular}{|l|c|c|c|c|c|}
\hline Traits & No. & Initial wt. Kg & Final wt. Kg & Daily gain. Kg & $\begin{array}{l}\text { Empty body } \\
\text { weight kg }\end{array}$ \\
\hline Overall mean & 24 & $11.9 \pm 0.29$ & $17.94 \pm 0.81$ & $0.06 \pm 0.008$ & $14.41 \pm 0.18$ \\
\hline Breed & 12 & $11.7 \pm 0.47 \mathrm{a}$ & $17.97 \pm 1.36 \mathrm{a}$ & $0.06 \pm 0.01 \mathrm{a}$ & $14.69 \pm 1.39 \mathrm{a}$ \\
\hline Meriz & 12 & $12.10 \pm 0.37 \mathrm{a}$ & $17.92 \pm 0.96 \mathrm{a}$ & $0.06 \pm 0.01 \mathrm{a}$ & $14.12 \pm 0.91 \mathrm{a}$ \\
\hline Goat & \multicolumn{5}{|l|}{} \\
\hline System & 8 & $11.68 \pm 0.73 \mathrm{a}$ & $21.08 \pm 1.61 \mathrm{a}$ & $0.10 \pm 0.01 \mathrm{a}$ & $17.73 \pm 1.37 \mathrm{a}$ \\
\hline Intensive & 8 & $12.03 \pm 0.45 \mathrm{a}$ & $18.28 \pm 0.52 \mathrm{a}$ & $0.06 \pm 0.008 \mathrm{~b}$ & $14.84 \pm 0.61 \mathrm{a}$ \\
\hline Semi-Intensive & 8 & $12.00 \pm 0.33 \mathrm{a}$ & $14.46 \pm 0.74 \mathrm{~b}$ & $0.02 \pm 0.005 \mathrm{c}$ & $10.66 \pm 0.85 \mathrm{~b}$ \\
\hline Extensive &
\end{tabular}

Within a column and comparison, means without a common superscript letter differ significantly. 
Also Al- Doori (2006) indicated that the growth rate of Awassi lambs fed a concentrate diet surpassed significantly those raised on stubble grazing supplemented with barley (294 vs. 116g/day).

Carcass characteristics Carcass characteristics are presented in Table 3. Dressing percentage based on full and empty live body weight averaged 38.24 and $47.36 \%$, respectively for Meriz and 37.28 and $47.44 \%$ for goat in the same order. The difference between them was not significant. Dressing percentages were lower than those reported by Mayi (2009) for Meriz and goat slaughtered at a heavier weight (25.08 Kg for Meriz and $39.31 \mathrm{Kg}$ for goat). The non-significant differences in dressing percentage were in accordance with those reported earlier by Mokhtar et al (1996), Dhanda et al. (1999) and Al-Doori (2006). However, breed differences in dressing- out percentage based on empty body weight or lack of them are influenced by degree of gut fill at slaughter (Kadim et al.,2003).

The dressing percentage based on live body weight and empty body weight of intensively raised kids (42.42 and 50.41\%) and semi-intensive group (40.24 and $49.66 \%)$ were significantly $(\mathrm{p}<0.01)$ higher than that of kids raised on pasture (30.61 and 42.14\%) (Table 3 ). This result was in accordance with the finding of Kor (1991) and Ertugrul (1994) who noticed that the dressing percentages of goats raised in pasture conditions was lower than that of intensively raised ones. On the other hand, Daskiran et al., (2006) reported that the dressing percentage of intensively raised Norduze male kids $(42.94 \%)$ was $3.32 \%$ lower than that of kids raised on pasture. Such difference may be attributed to variations in weight of digestive tract content (Dhanda et al.,1999).

Differences between breeds in rib eye area, fat thickness and shrinkage percentage lacked significance. Similarly, Oman et al., (1999) indicated that there were no significant differences between the Boer $\times$ spanish range goats and the Spanish range goats in rib eye area and fat thickness. Al-Doori (2006) also, reported that genotype (native goat and their crosses with Saanen or Shami) had no significant effect on the studied traits.

Kids raised on concentrate diet possessed significantly $(\mathrm{p}<0.01)$ larger rib eye area, greater fat thickness $(p<0.01)$ and lower shrinkage percent $(p<0.01)$ than those raised on pasture. Also, Oman et al. (1999) reported that feedlot goats carcasses had larger rib eye area and greater fat thickness than did range goat carcasses Diets have been found to affect carcass traits in other species. Tatum et al. (1985) reported that lambs fed in a feedlot produced fatter carcasses than lambs fed limited or no grain. Several studies have verified this for beef cattle as well (Burson et al., 1980; Schroeder et al., 1980).

In contrast, Norduz goat male kids raised in pasture had larger Musculus longissimus dorsi than intensively raised ones, while fat content of intensively raised kids was higher than that of other group (Daskiran et al.,2006). A significantly $(p<0.01)$ greater loss in shrinkage percent of kids carcasses raised on pasture compared to other groups can be attributed to their thin subcutaneous fat cover (Table 3 ). 


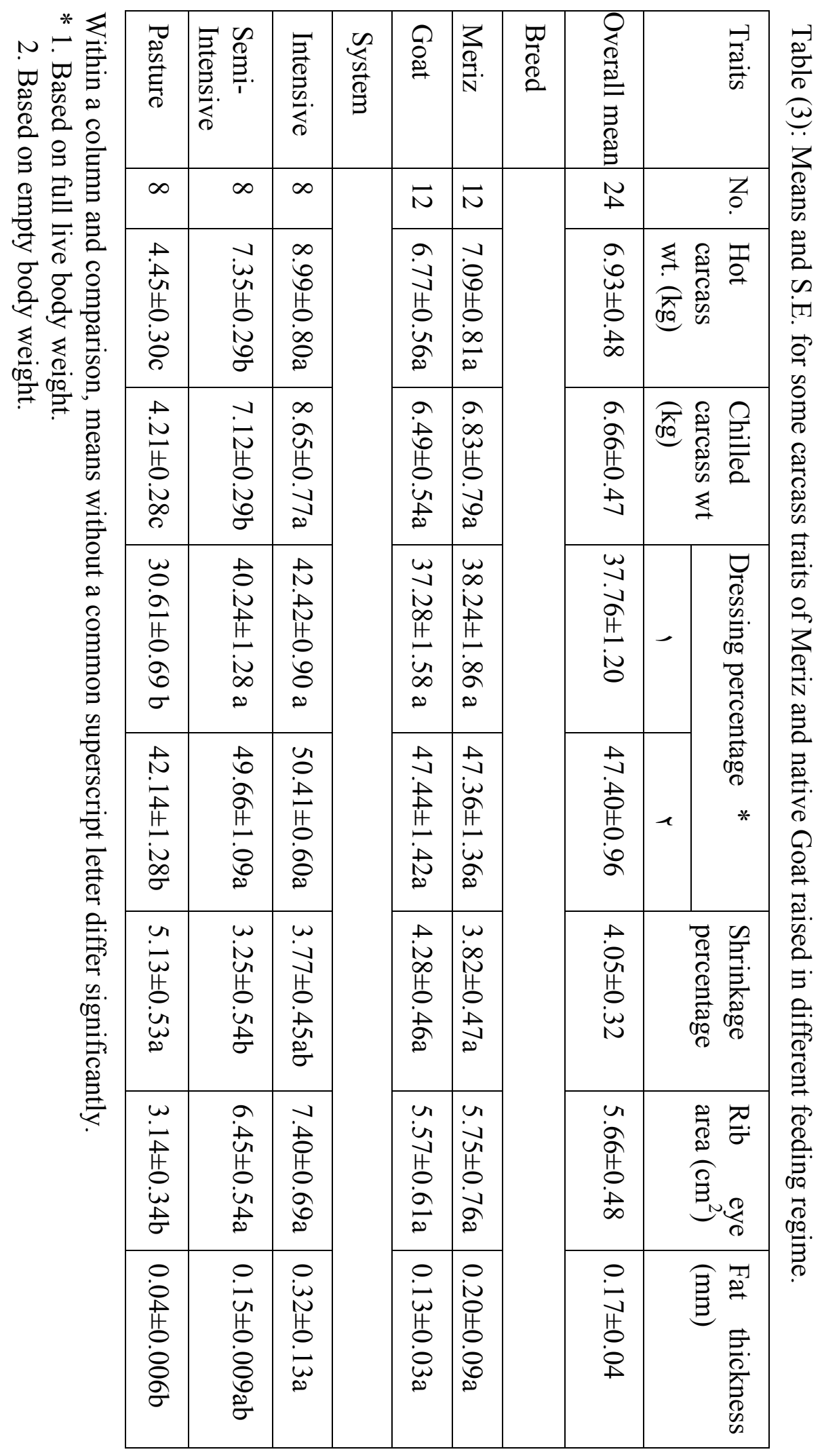


Edible and non-edible organs: Weights of edible and non-edible organs together with their percentages as a proportion of empty body weights are demonstrated in Table 4. With the exception of weight and percentage of pelt and percent feet, all other organs were not significantly affected by breed. Yet, Meriz had significantly higher pelt weight $(1.66 \pm 0.09 \mathrm{Kg})$ than goat $(1.47 \pm 0.08 \mathrm{Kg})$, and consequently had higher percent (13.00 vs. $10.49 \%)$ which may be attributed to heavier hair cover of the Meriz which resulted in heavier pelt than goats. Kadim et al., (2003) also, reported significant differences between breeds for some organs including skin and feet. Also, the percent feet of goat were significantly higher than Meriz (3.34 vs $3.01 \%$ ) the heavier feet of goat kids are partially explained in terms of the distinctly long legs of this breed. Previously, Mokhtar et al., (1996) found that Jamnabary $\times$ Aradi showed higher weight of feet than Damascus $\times$ Aradi.

Table (4): Means and S.E. for some edible and non edible organs of Meriz and native Goat raised in different feeding regime.

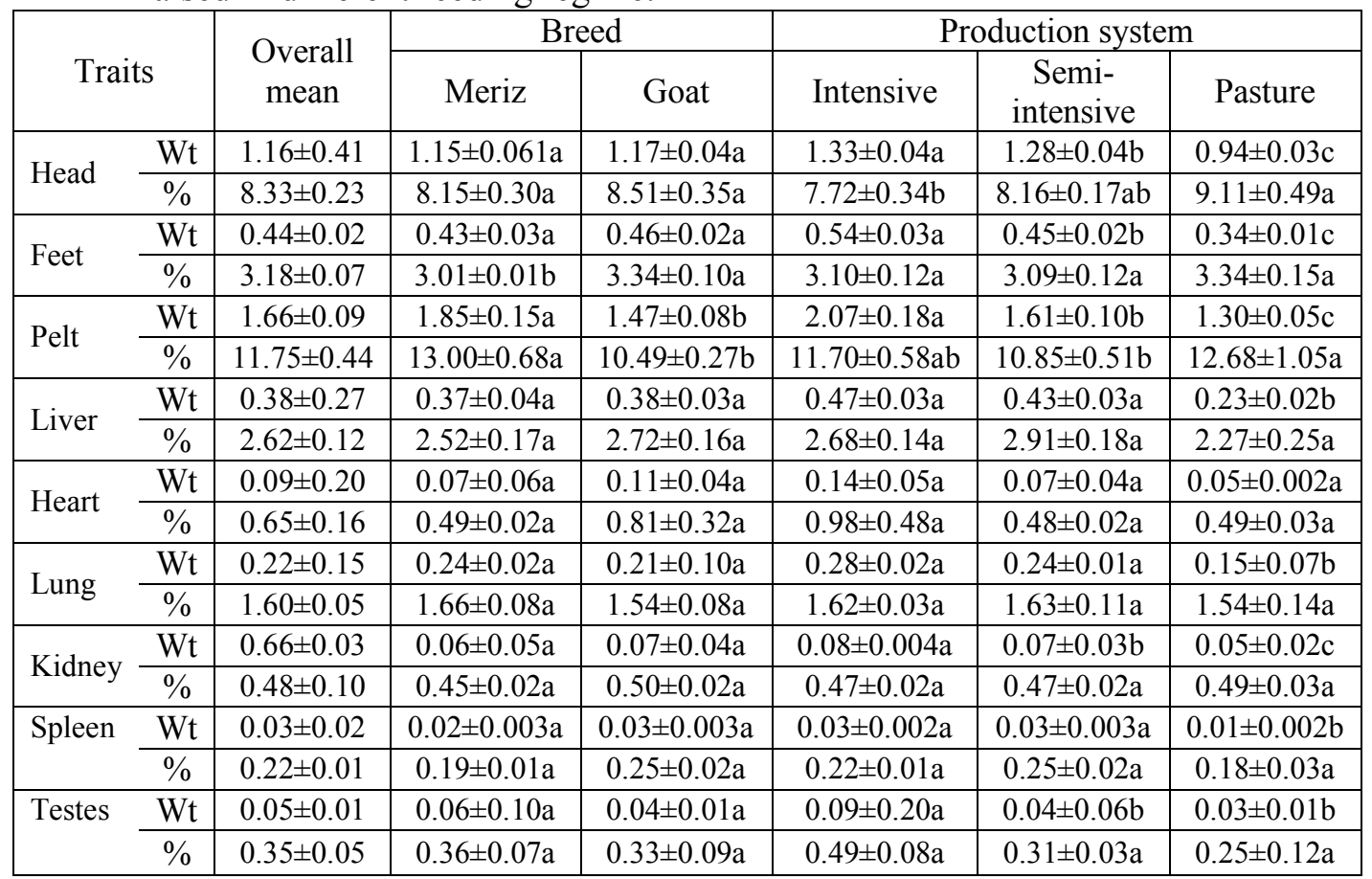

Within a row and comparison, means without a common superscript letter differ significantly.

The proportions of various visceral organs reported in the present study were similar to those reported for different breeds of goats (Gibb et al., 1993, Tahir et al., 1994, Johnson et al., 1995; Mahgoub and Lodge, 1996 and Kadim et al., 2003). The weight of all visceral organs of kids raised intensively was significantly heavier than kids raised on pasture. However, only the percentages of head and pelt were significantly higher for kids fed on pasture compared to the other groups. Working with Norduz male kids, Daskiran et al., (2006) on the other hand, stated that neither weight nor the percentage of head, feet and pelt differ significantly between kids raised intensively or on pasture conditions. However, the weights of heart, lung and liver were heavier significantly for kids raised intensively compared to those fed on pasture. 
It can be concluded that feeding Meriz and goats on concentrate results in heavier live and carcass weights, higher dressing percentage and fatter carcasses when compared to those raised on pasture. Further research should focus on determining the cost and the net return for each system of production.

Acknowledgment: I would like to thank prof. Dr. Jalal E. AlKass, Department of animal production for his valuable help in reading the manuscript.

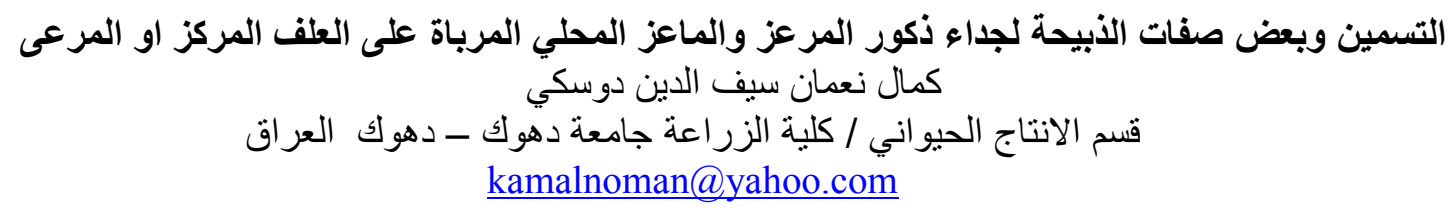

\section{REFERENCES}

Al-Doori, Z. T. O. (2006). Effect of fattening system in growth features and carcass for Awassi lambs. Ph. D. Thesis, College of Agriculture, University of Baghdad.

Alkass, J. E. and K. H. Juma (2005). Small Ruminant Breeds of Iraq. In: Characterization of Small Ruminant Breeds in West Asia and North Africa (Editor, Luis Iniguez). Vol. 1. West Asia. International Center of Agriculture Research in the Dry Areas (ICARDA)., Aleppo, Syria, pp.63-101.

Alkhawaja, A. K., S. A. Matti, R. F. Asadi, K. M. Mokhtar and S. H. Aboona (1978). the composition and nutritive value of Iraqi feedstuffs, Division Publication, Ministry of Agriculture, Iraq.

Anous, M. R. and M. M. Mourad (1993). Crossbreeding effects on reproductive traits of does and growth and carcass traits of kids. Small Rumen Res.12:141149.

Ayied, A.Y. (1996). Effect of crossing Iraqi native goat with Shami and Saanen goats on kid performance and other economical traits. Ph.D. Thesis. College of Agriculture. Basrah University. (Arabic).

Banskalieva, V., T. Sahlu and A. L. Goetsch (2000). Fatty acid composition of goat muscles and fat depots: a review. Small Rumin Res. 37, 255-268. 
Burson, D. E., M. C. Hunt, D. M. Allen, C. L. Kasmer and D. H. Kropf (1980). Diet energy density and time on feed effects on beef longissimus muscle palatability. J. Anim. Sci. 51:875-881.

Duncan, D. B. 1955. Multiple Range and Multiple Test Biometric.11:1.

Daskiran, I., A. Kor, and M. Bingol (2006). Slaughter and carcass characteristics of Norduz male kids raised in either intensive or pasture conditions. Pakistan Journal of Nutrition 5 (3): 274-277.

Dhanda, J. S., D. G. Taylor, J. E. McCosker and P. J. Murray (1999). The influence of goat genotype on the production of Capretto and Chevon

carcasses. 1. Growth and carcass characteristics. Meat Sci. 52:355-361.

Ertugrul, M., (1994). Slaughter and carcass characteristics of Angora male kids intensively fed at weaning period and extensively raised (in Turkish). Ankara University, Ankara. (Cited by Daskiran et al., 2006).

FAO ( Food and Agriculture Organization) (2000). Quarterly Bulletin of Statistics Vol-1 FAO, Rome, Italy.

Gibb, M. J., J. E. Cook and T. T. Treacher (1993). Performance of British Saanen, Boer x British Saanen and Anglo-Nubian castrated male kids from 8 week to slaughter at 28, 33 or $38 \mathrm{Kg}$ live weight. Anim. Prod. 57:263-271.

Johnson, D. D., C. H. McGowan, G. Nures and M. R. Anous (1995). Breed type and sex effects on carcass traits, composition and tenderness of young goat. Small Rumen. Res . 17:57-63.

Kadim, I.T., O. Mahgoub, D. S. Al-Ajmi, R. S. Al-Maqbaly, N.M. Al-Saqri and A. Ritchie (2003). An evaluation of the growth, carcass and meat quality characteristics of Omani goat breeds. Meat Science 66: 203-210.

Kanaujia, A. S., A. K. Vinayak and D. S. Balaine (1985). Growth and carcass traits of Beetal, Black Bengal and their crosses. Indian J. Anim. Sci.55:496-499.

Kor, A., (1991). The growth performance and carcass characteristics of Damascus $\mathrm{x}$ Hair Goat (F1) crossbred male kids. MSc. Thesis. University of Cukurova,Turkey.

Lu, C. D. and M. J. Potchoiba (1990). Feed intake and weight gain of growing goats fed diets of various energy and protein levels. J. Anim. Sci. 68:17511759.

Mahgoub, O. and G. A. Lodge (1996). Growth and body composition in meat production of Omani Batina goats. Small Rumin. Res. 19:233-246.

Mayi, V. J. T. (2009). Effect of fattening period on growth rate and carcass characteristics of Meriz and native black goats. MSc. Thesis. College of Agriculture. University of Duhok.

McGregor, B. A. (1985). Growth, development, and carcass composition of goats: a review. In: Goat production and Research in the Tropics. J. Copland (Editor). Prceesdings of a workshop held at the University of Queensland, Brisbane, Australia. 6-8 February 1984. Pp 82-90. 
Mokhtar, S. A., S. El Kaschab and I. O. Soliman (1996). Effect of crossing native goats using improved sires of Damascus and Jamnabary breeds on slaughter weight and carcass composition. World Review of Animal Production. 31:105112.

Oman, J. S., D. F. Waldron, D. B. Griffin and J. W. Savell (1999). Effect of breedtype and feeding regimen on goat carcass traits. J Anim. Sci. 77:3215-3218.

Potchoiba, M. J., C. D. Lu, F. Pinkerton, and T. Sahlu (1990). Effects of all-milk diet on weight gain, organ development, carcass characteristics and tissue composition, including fatty acid and cholesterol contents of growing male goats. Small Rumin Res. 3, 583-592.

SAS / STAT. (2001). User's guide for personal computers. Release 6-12 SAS Institute, Cray N. C., USA.

Schroeder, J. W., D. A. Cramer, R. A. Bowling, and C. W. Cook (1980). Palatability, shelflife and chemical differences between forage- and grainfinished beef. J. Anim. Sci. 50:852-859.

Stankov, Iv.K., N. A.Todorov, J. E.Mitev, and T. M. Miteva (2002). Study on some qualitative features of meat from young goat of Bulgarian breeds and crossbreds of goats slaughtered at various ages. Asian-Australian J. Anim. Sci. $15,283-289$.

Tahir, M. A., A. F. Al-Jassim, and A. H. H. Abdulla (1994). Influence of live weight and castration on distribution of meat, fat and bone in the carcass of goats. Small Rumin. Res. 14: 219-223.

Tatum, J. D., J. W. Savell, H. R. Cross, and J. G. Butler (1989). A national survey of lamb carcass cutability traits. SID Res. J. 5(1):23-31. 